\title{
Самойлова Д.В. \\ К вопросу о Фонде защиты прав граждан-участников долевого строительства
} ФГАОУ ВО «Дальневосточный федеральный университет» (ДВФУ) (Россия, Владивосток)

doi: $10.18411 / l j-05-2021-196$

\section{Аннотация}

В статье рассматривается возможность решения проблемы «обманутых дольщиков» путем создания Фонда защиты прав граждан-участников долевого строительства. Исследуются публично-правовые характеристики Фонда, анализируются его функции и полномочия, особое внимание уделяется функции Фонда, направленной на завершение строительства проблемных объектов.

Ключевые слова: Фонд защиты прав граждан-участников долевого строительства, застройщик, участник долевого строительства, страхование ответственности.

\section{Abstract}

The article considers the possibility of solving the problem of "deceived shareholders" by creating a Fund for the Protection of the Rights of citizens participating in shared-equity construction. The article examines the public-legal characteristics of the Fund, analyzes its functions and powers, and pays special attention to the Fund's function aimed at completing the construction of problematic objects.

Keywords: Foundation for the Protection of the Rights of Citizens - participants of shared construction, developer, participant of shared construction, liability insurance.

За предыдущие несколько лет, особенно за три предшествующих года, тема долевого строительства и проблема «обманутых дольщиков» при учете их масштаба и сложности стали одними из приоритетных по необходимости решения и для федеральных, и для региональных уровней государственной власти, поскольку касаются важной потребности любого человека - потребности в жилье.

До 2013 года в Российской Федерации обеспечение исполнения обязательств застройщика в сфере долевого строительства осуществлялось посредством залога или поручительства.

С 1 января 2014 года вступили в законную силу изменения, которые ввели обязательное страхование ответственности застройщика. Согласно новым требованиям, привлечение денежных средств граждан в долевое строительство жилья должно было подлежать страхованию либо посредством коммерческого страхования или поручительства банка, либо посредством участия строительных организаций в Обществе взаимного страхования гражданской ответственности застройщиков (OBC).

Механизм страхования ответственности застройщика перед дольщиками за неисполнение либо ненадлежащее исполнение обязательств по договору участия в долевом строительстве предусматривал, что в случае банкротства застройщика страховая компания могла бы возместить дольщикам потерянные деньги. Однако, как показывала практика применения данного механизма, главная проблема заключалась в том, что страховые компании зачастую были не готовы произвести выплаты участникам долевого строительства.

Практика 2015-2016 годов показала, что механизм страхования ответственности застройщика работает плохо и участники долевого строительства крайне редко могут получить реальную компенсацию по такой страховке.

Для решения некоторых несовершенств в системе жилищного страхования законодателями был принят Федеральный закон от 29.07.2017 № 218-Ф3 «О публичноправовой компании по защите прав граждан - участников долевого строительства при 
несостоятельности (банкротстве) застройщиков и о внесении изменений в отдельные законодательные акты Российской Федерации».

Суть данного закона заключается в создании публично-правовой компании «Фонд защиты прав граждан - участников долевого строительства» в целях реализации государственной жилищной политики, направленной на повышение гарантии защиты прав и законных интересов граждан - участников долевого строительства, средства которых привлекаются для строительства многоквартирных домов или жилых домов блокированной застройки, состоящих из трех и более блоков, по договорам участия в долевом строительстве.

В соответствии с Постановление Правительства РФ от 07.10.2017 № 1231 Фонд создается путем преобразования некоммерческой организации «Фонд защиты прав граждан - участников долевого строительства», созданной в организационно-правовой форме фонда, учредителем которой является Российская Федерация, и является ее правопреемником.

Страхование в сфере строительства по новому закону является объединением коммерческого и некоммерческого страхования, так как застройщики делают отчисления в данный фонд в равной степени (1,2 процента от цены договора), и, при наступлении страхового случая, возмещение будет происходить из данного фонда. Происходит обмен рисками застройщиков, но при этом данный фонд, как и страховые организации, находится под влиянием органов государственной исполнительной власти.

Создание Фонда является важным шагом в решении проблем участников долевого строительства. Главное преимущество Фонда в том, что он основан на государственном участии и наделен функциями и полномочиями, характерными для государственной власти. Следует отметить, что именно правовой статус Фонда позволяет обеспечить высокий уровень защиты нарушенных прав.

Высокая надежность созданного Фонда обусловлена его организационноправовой формой, так как в соответствии со ст. 65 ГК РФ публично-правовая компания не может быть признана несостоятельной (банкротом).

Важное значение имеет то обстоятельство, что в отношении Фонда осуществляется особый государственный контроль. Так, Счетная палата осуществляет государственный аудит Фонда, за Фондом закреплена обязанность составления ежегодной финансовой отчетности. Указанные мероприятия направлены на предотвращение нецелевого использования отчислений и на строгий контроль за их расходованием. В отношении страховых организаций, обеспечивающих ответственность застройщика, подобные меры по контролю не проводились.

Также полномочия Фонда позволяют ему контролировать деятельность застройщика: по запросам Фонда застройщик обязан предоставить Фонду бухгалтерскую (финансовую) отчетность. Также законом предусмотрено принятие Фондом контрольных мер на случай отклонения застройщика от графика реализации проекта на шесть и более месяцев.

Большое значение для граждан имеет функция Фонда, направленная на завершение строительства. Благодаря финансированию Фондом мероприятий по завершению строительства, участники долевого строительства в случае банкротства застройщика имеют возможность получить жилое помещение, а значит, достигнуть той цели, ради которой был заключен договор.

Так, например, дома жилого комплекса Восточный (жилые дома № 9, 10, 13) проходят процедуру завершения строительства в соответствии с Ф3-218, дострой жилых комплексов осуществляется Фондом на основании принятого решения о целесообразности финансирования мероприятий по завершению строительства. 
Решение о целесообразности либо о нецелесообразности финансирования строительства объектов принимает Фонд за счет компенсационного фонда, а также за счет имущества Фонда, сформированного за счет имущественного взноса РФ и иных публично-правовых образований, на основании Правил, утвержденных Постановлением Правительства РФ от 12.09.2019 № 1192.

В целом, по итогам 2020 года Фондом было завершено строительство 17 объектов, что на 3 дома больше, чем в 2019 году. Также увеличилось количество объектов, по которым было принято решение о целесообразности финансирования строительства: с 82 до 367 жилых объектов, по сравнению с 2019 годом.

В том случае, если Фонд принимает решение о нецелесообразности финансирования строительства, то участникам долевого строительства выплачивается компенсация. Решение о выплате компенсации принимается при ситуации, когда, сравнивая суммы, необходимые для завершения строительства с суммой возмещения, последняя оказывается меньше.

Возмещение участникам долевого строительства выплачивается в размере рыночной стоимости жилого помещения, определенной на дату, которая не может быть более чем на три месяца ранее даты принятия Фондом решения о выплате возмещения, но не менее уплаченной цены договора (ч. 2, 2.1 ст. 13 Закона N 218-Ф3).

Создание публично-правовой компании, наделённой специальными полномочиями, сможет гарантировать участникам долевого строительства соблюдение их прав, а в случае их нарушения обеспечит их эффективную защиту и восстановление. При этом важную роль в реализации этих процессов выполняет то обстоятельство, что отчисления застройщиков будут находиться именно в государственном Фонде, а не у различных коммерческих организаций.

Отечественный законодатель уже довольно продолжительное время пытается снизить риски участников долевого строительства путем применения страхования ответственности застройщиков. Изначально, в 2014 году был введен механизм обязательного страхования ответственности застройщика, который, как показала практика, оказался малодейственным и не смог оказать положительное воздействие на решение проблемы «обманутых дольщиков», в следствие чего в 2017 году было принято решение о создании на федеральном уровне Фонда защиты прав граждан участников долевого строительства, цель которого состоит в исключении финансового риска для граждан, покупающих квартиру в строящемся доме, защите их прав и интересов в случае банкротства застройщика, а также создании на территории РФ безопасного и честного рынка долевого строительства.

$$
* * *
$$

1. Гражданский кодекс Российской Федерации. Часть первая: федер. закон от 30.11.1994 № 51-Ф3 // Собр. законодательства Рос. Федерации. 1994. № 32. Ст. 3301. 2018. № 30. Ст. 4552 (ред. от 09.03.2021).

2. О публично-правовой компании «Фонд защиты прав граждан - участников долевого строительства»: постановление Правительства от 07.10.2017 № 1231 // Собр. законодательства Рос. Федерации. 2017. Ст. 3457.

3. Постановление Правительства РФ от 12 сентября 2019 г. N 1192 «Об утверждении Правил принятия решения публично-правовой компанией «Фонд защиты прав граждан - участников долевого строительства» о финансировании или о нецелесообразности финансирования мероприятий, предусмотренных пунктом 2 части 1 статьи 12, частью 2 статьи 13.1 Федерального закона «О публично-правовой компании по защите прав граждан - участников долевого строительства при несостоятельности (банкротстве) застройщиков и о внесении изменений в отдельные законодательные акты Российской Федерации» и о признании утратившими силу некоторых актов Правительства Российской Федерации» $\square$ Электронный ресурс $\square$. Режим 
доступа: https://www.garant.ru/products/ipo/prime/doc/72631446/ Загл. с экрана (дата обращения: 01.05.2021).

4. Кошукова, К. И. Актуальные проблемы защиты прав граждан, участвующих в долевом строительстве / К.И. Кошукова // Молодой ученый. 2018 . № 47 (233). С. 85-87.

5. О публично-правовой компании по защите прав граждан - участников долевого строительства при несостоятельности (банкротстве) застройщиков и о внесении изменений в отдельные законодательные акты Российской Федерации: федер. закон от 29.07.2017 № 218-Ф3 // Рос. газета. 2017. № 169. 2019. № 140 (ред. от 30.12.2020).

6. Смирнова, Д.С. Влияние создания компенсационного фонда защиты дольщиков на строительную отрасль России / Д.С. Смирнова // Научные записки молодых исследователей. 2017. № 3. С. 12-19.

7. Шохин, А.Н., Палагина, А.А. Взаимодействие государства и строительного бизнеса в процессе перехода от отношений долевого участия к проектному финансированию: предпосылки и рекомендации по определению негативных последствий / А.Н. Шохин, А.А. Палагина // Бизнес. Общество. Власть. 2018. № 2 (28). С. 60-75.

\section{Смирнов Н.Д., Евтухов И.В. \\ Проблемы медиации в современной России}

Кубанский государственный аграрный университет имени И.Т. Трубилина (Россия, Краснодар)

doi: 10.18411/lj-05-2021-197

\section{Аннотация}

В данной статье авторы рассматривают процедуру медиации в современной России. Был проведён анализ практических и теоретических аспектов в деятельности института медиации, также было изучено действующее законодательство, специальная литература и научные работы в сфере медиации. Авторами раскрыто содержание актуальных для Российской Федерации проблем в области медиации и предложены пути и методы их решения.

Ключевые слова: медиация, медиатор, альтернативные способы урегулирования споров, примирение сторон, гражданский процесс.

Abstract

In this article, the authors consider the procedure of mediation in modern Russia. The analysis of practical and theoretical aspects in the activities of the Institute of Mediation was carried out, and the current legislation, special literature and scientific works in the sphere of mediation were studied. The authors explain the content of the mediation problems of the Russian Federation and suggest ways and methods of solving them.

Keywords: mediation, alternative dispute resolution, reconciliation of the parties, civil procedure.

Медиация - это урегулированный способ внесудебного разрешения спора, где третья сторона - посредник (медиатор) сохраняет нейтральность.

В большинстве случаев, если стороны спора решают проблему путем обсуждения, они могут гораздо быстрее подойти к финалу и добиться наиболее эффективного результата, чем суд. Но, к сожалению, лишь небольшая часть дел, расследуемых судом, разрешается посредством медиации. По официальным данным Высшего Арбитражного Суда РФ, в рамках арбитража с использованием процедуры медиации в арбитражной системе рассматривается 10 в 2012 году, 11 в 2013 году и почти полтора миллиона дел в год[1]. Хотя широкое использование медиации могло бы снизить нагрузку на суды и оказать положительное влияние на всю систему правосудия.

Мы считаем, что главным образом неэффективность современного института медиации связана с недостаточной деятельностью по отношению к населению и отсутствие поддержки правильной поддержки со стороны государства, так как на 